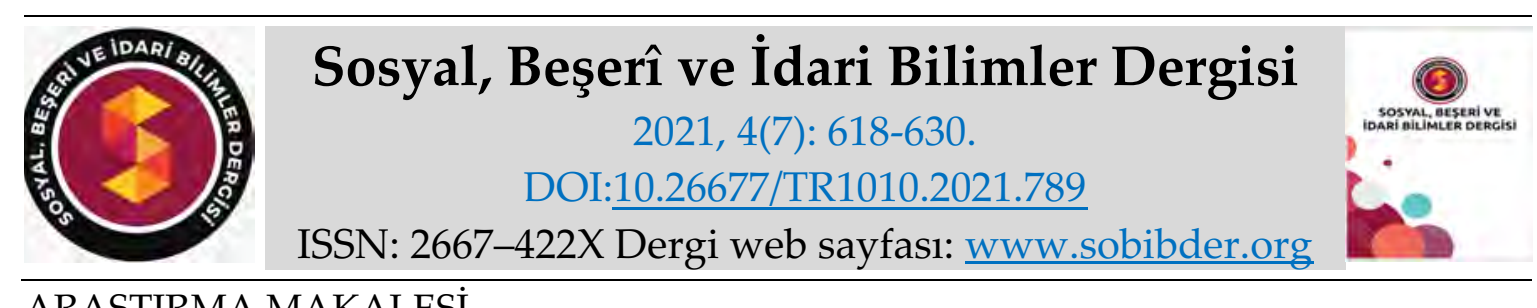

ARASTTIRMA MAKALESI

\title{
Uluslararası Öğrencilerin Dil Becerilerinin Mevcut Durum Analizi: Pamukkale Üniversitesi Örneği*
}

Öğr. Gör. Mevlüt ELLİALTI, Uşak Üniversitesi, Lisansüstü Eğitim Enstitüsü, Uşak, e-posta: mellialti@pau.edu.tr ORCID: https://orcid.org/0000-0002-5151-6491

Prof. Dr. Zekerya BATUR, Uşak Üniversitesi, Eğitim Fakültesi, Uşak, e-posta: zekerya.batur@usak.edu.tr

ORCID: https://orcid.org/0000-0002-7918-5305

Öz

Bu çalışma Türkçe hazırlık programından sonra lisans veya lisansüstü düzeyinde eğitim gören uluslararası öğrencilerin dil becerileri bakımından mevcut durumlarının nasıl olduğunu, hazırlık eğitiminde öğrenilen dilin yeterli olup olmadığını ve okudukları programlarda karşılaştıkları sorunların neler olduğunu ortaya koymayı amaçlamaktadır. Çalışmada Pamukkale Üniversitesi'nde çeşitli sınıflarda öğrenim görmekte olan uluslararası öğrencilerin mevcut dil durumlarını ortaya koymak amacıyla Ulutaş (2016) tarafından hazırlanan Mevcut Durum Analizi (MDA) anketi uygulanmıştır. Çalışma sonucunda elde edilen bulgulara göre 1) katılımcıların kendilerini en iyi olarak değerlendirdikleri beceri dinlemedir, 2) katılımcıların kendilerini en kötü olarak değerlendirdikleri beceri yazmadır, 3) katılımcılar akademik başarı için en önemli becerinin dinleme olduğunu düşünmektedir, 4) katılımcılar yazma becerisinin akademik başarı için en az etkiye sahip olduğunu düşünmektedir, 5) katılımcılar en çok alanlarıyla ilgili bir dersi ve konuşmayı dinlerken konuyu özetleyerek not tutmakta; yazdıkları yazılarda, anlam bütünlüğü olan paragraflar oluşturmakta ve alanlarıyla ilgili bir metni hızlı okurken metnin konusunu belirlemekte sorun yaşadıklarını belirtmektedir.

* Bu çalışma, Mevlüt ELLİALTI tarafından Uşak Üniversitesi Lisansüstü Eğitim Enstitüsü'nde Doç. Dr. Zekerya BATUR danışmanlı̆̆ında yürütülen "Yabancı Dil Olarak Türkçe Öğretiminde Akademik Dinleme Becerisinin Geliştirilmesi" başlıklı doktora tezinden üretilmiştir.

Anahtar Kelimeler: Mevcut Durum Analizi, İhtiyaç Analizi, Yabancı Dil Olarak Türkçe, Dil Becerileri.

Makale Gönderme Tarihi: 18.04.2021

Makale Kabul Tarihi: 03.07.2021

\section{Önerilen Atıf:}

Ellialtı, M. ve Batur, Z. (2021). Uluslararası Öğrencilerin Dil Becerilerinin Mevcut Durum Analizi: Pamukkale Üniversitesi Örneği, Sosyal, Beşeri ve İdari Bilimler Dergisi, 4(7): 618-630.

C 2021 Sosyal, Beşerî ve İdari Bilimler Dergisi. 


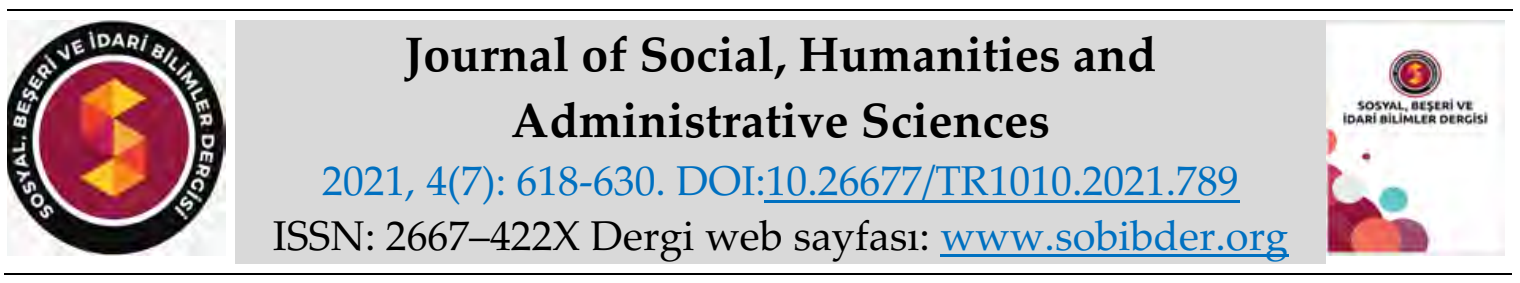

RESEARCH PAPER

\title{
An Analysis of the Current State of International Students' Language Skills: The Example of Pamukkale University
}

Lecturer Mevlüt ELLİALTI, Uşak University, Graduate Education Institute, Uşak, e-mail: mellialti@pau.edu.tr

ORCID: https://orcid.org/0000-0002-5151-6491

Prof. Dr. Zekerya BATUR, Uşak University, Faculty of Education, Uşak, e-mail: zekerya.batur@usak.edu.tr

ORCID: https://orcid.org/0000-0002-7918-5305

\begin{abstract}
This study aims to analyse the current state of international students' linguistic skills after having Turkish language preparatory courses. Furthermore, it is aimed to find out the efficiency of the language, learnt at the preparatory program, and the language problems that the students confront at their departments for the first year. In this study Ulutaş (2016)'s "Present Situation Analysis Questionnaire (PSAQ)" was used to investigate current state of international students' linguistic skills in Turkish language. The data were collected from 64 participants who attended the preparatory program for Turkish language at Pamukkale University. As the result of the research 1) participants evaluate themselves as very good at listening, 2) participants evaluate themselves as very bad at writing, 3) participants think that listening is the most important skill to be successful at their departments, 4) participants think that writing is the least important skill to be successful at their departments, 5) participants have difficulties in taking notes and summarizing while they are listening to a lecture; in building content integrated paragraphs; and in determining the topic of the texts while they are reading fast.
\end{abstract}

Keywords: Present Situation Analysis, Needs Analysis, Turkish as a Foreign Language, Language Skills.

Received: 18.04 .2021

Accepted: 03.07.2021

Suggested Citation:

Ellialtı, M. and Batur, Z. (2021). An Analysis of the Current State of International Students' Language Skills: The Example of Pamukkale University, Journal of Social, Humanities and Administrative Sciences, 4(7): 618-630.

(c) 2021 Sosyal, Beşerî ve İdari Bilimler Dergisi. 


\section{Gíriş}

İhtiyaçlar öğrencinin ne bildiğini ne bilmediğini veya neyi bilmek istediğini içerir ve farklı yollarla toplanıp analiz edilebilir (Hyland, 2006). İhtiyaç analizi kazanımların belirlenmesinde ve program içeriğinin oluşturulmasında önemli bir yere sahiptir. İhtiyaç analizinin kullanılması dil derslerinin şekillendirilmesinde, geliştirilmesinde, öğrenme materyallerinin oluşturulmasında ve değerlendirilmenin yapılmasında en önemli adımdır (Rahman, 2015; Long, 2005; Dudley Evans ve St John, 1998; Jordan, 1997; Robinson, 1991). İhtiyaç analizinin gerçekleştirilmesi dil derslerinin her bir aşamasında etkinli ve verimli bir öğretim ortamının oluşturulmasında büyük katkı sağlar. West (1994) ihtiyaç analizinin dil öğretim programı için pragmatik bir gereklilik olduğunu savunurken ihtiyaç analizi yapılmayan bir dil öğretimi programının başarısının hep tartışma konusu olacağı düşünülmektedir. Öğrencilerin gereksinimleri belirlendiğinde aynı zamanda hedefleri de belirlenmiş olur. Bu çerçevede de testler, materyaller ve öğretim etkinlikleri de tasarlanabilir (Brown, 1995). İhtiyaçların analizi ile öğrenciler, program ve öğretmen hakkında detaylı bilgilerin alınması sayesinde mevcut programın gözden geçirilmesi ve değerlendirilmesi de mümkün olabilmektedir (Richards, 1984).

İhtiyaçlar birçok araştırmacı tarafından farklı yönleriyle boyutlandırılmıştır. Berwick (1989) hissedilen ve algılanan ihtiyaçlar olarak; Richterich ve Chancerel (1980) öznel ve nesnel ihtiyaçlar olarak Brown (1995) durum ve dil ihtiyaçları olarak ihtiyaçları ayırmışlardır. Çalışkan ve Çangal (2013)'ın çeşitli kaynaklardan derlediği bilgiye göre ihtiyaç analizinde sistematik, sosyolengüistik, öğrenme merkezli, öğrenci merkezli ve görev temelli olmak üzere beş temel yaklaşım bulunmaktadır. Masuhara (2013) ihtiyaç analizlerini öğrenci ihtiyaçları (kişisel ihtiyaçlar, öğrenme ihtiyaçları ve gelecekteki mesleki ihtiyaçlar), öğretmen ihtiyaçları (kişisel ve mesleki ihtiyaçlar) ve örgüt ihtiyaçları (kurumsal ihtiyaçlar) olmak üzere üç farklı boyutta değerlendirmektedir (akt. Arroyyani ve Nurhayati, 2019).

Ali (2011)'ye göre dil öğrenme ihtiyaçları analizinin hedef durum analizi (HDA) ve mevcut durum analizi (MDA) olmak üzere iki temel bileşeni vardır. HDA, Hutchinson ve Waters (1987)'ın modeli ile açıklanabilir. Hutchinson ve Waters (1987) ihtiyaçları iki türde sınıflandırmaktadır: Hedef ihtiyaçlar ve öğrenme ihtiyaçları. Hedef ihtiyaçlar, amaçlanan durumlar için öğrencilerin ihtiyaçlarını kapsamaktadır. Bu ihtiyaçlar da üç başlıkta değerlendirilmektedir: gereklilikler, eksiklikler ve istekler. İlki öğrencilerin amaçlanan durumlarda sahip olunması gereken deneyimler ve programın sonunda gerçekleştirilmesi beklenen kazanımlar olan gerekliliklerdir. İkincisi öğrencilerin neyi öğrenmeleri gerektiği ile mevcut durumda neyi ne kadar bildiklerini ortaya koyan eksikliklerdir. Sonuncusu ise öğrencilerin neye ihtiyacının olduğunu düşündüğü, kişisel amaçlarını ortaya koyan isteklerdir. İkinci tür olan öğrenme ihtiyaçları öğrencilerin nasıl öğrendiğini kapsamaktadır. Hutchinson ve Waters (1987)'a göre dersin yalnızca hedef kazanımlar üzerinde planlanması yeterli değildir. Ders aynı zamanda öğrenme durumlarının da dikkate alındığı bir çerçevede oluşturulmalıdır. Öğrenme durumu, öğrencinin bilgi düzeyi, becerileri, stratejileri, motivasyon kaynakları da planlama için doğru göstergelerdir.

Mevcut durum analizi ile dil, dil becerileri ve öğrenme deneyimlerinin öngörülebildiğini ifade etmektedir (Dudley-Evans ve St. John, 1998:124). Richterich ve Chancerel (1980) ihtiyaç analizinin devam eden bir süreç olduğunu, ders süresince ve dersten sonra ihtiyaç analizinin yapılmasının uygun olacağını savunmaktadır. Richterich ve Chancerel (1980) 'e göre üç temel bilgi kaynağı vardır: öğrencilerin kendileri, dil öğretim kurumu (öğretmenler) ve öğrencilerin dili kullandığ yer. Bu üç bilgi kaynağından sağlanan veriler doğrultusunda ihtiyaç analizleri yapılabilir ve sağlıklı veri elde edilebilir. MDA ile öğrencilerin mevcut durumları ve seviyeleri kolaylıkla 
açiklanabilir. Bu analiz aynı zamanda öğrencilerin şu andaki durumu ile ulaştığı düşünülen (hedeflenen) durumu arasındaki farkı da görmemizi sağlar (Gürler, 2018). Kısaca MDA öğrencilerden ve kurumlardan elde edilen verileri kullanarak verilen dil eğitiminin bir çeşit değerlendirmesi de yapmış olur.

Alanyazın tarandığında, yabancı dil olarak Türkçe öğretimi alanında çeşitli ihtiyaç analizleri gerçekleştirilmiştir. Analizlerin bir kısmı hedef durum analizi, bir kısmı ise mevcut durum analizi şeklinde gerçekleştirilmiştir. Yapılan ihtiyaç analizleri doğrultusunda öğrencilerin karşılaştıkları çeşitli sorunlar tespit edilmeye, farklı noktalarda beklentileri ortaya konmaya, ders planlamaları ve içerikleri oluşturulmaya çalışılmıştır (Konyar ve Yılmaz, 2021; Çelik ve İpek, 2019; Deliktaş, 2019; Demir ve Genç, 2019; Haidari ve Yelken, 2018; Demir ve Genç, 2018; Demir, 2017; Yılmaz ve Konyar, 2017; Başar ve Akbulut, 2016; Gürbüz ve Güleç, 2016; Ulutaş, 2016; Şahin ve Demirtaş, 2014; Çalışkan ve Çangal, 2013; Tok, 2013; Çalışkan ve Bayraktar, 2012).

Yükseköğretim bilgi sisteminden alınan veriler 1şığında 2019/2020 yılında Pamukkale Üniversitesinde öğrenim görmekte olan uluslararası öğrenci sayısı 741 'dir ve 5 yıl önce ise bu sayı 376'dır (https://istatistik.yok.gov.tr). Pamukkale Üniversitesi'nde öğrenim gören öğrenciler başta Pamukkale Üniversitesi Dil Öğretimi Uygulama ve Araştırma Merkezi (PADAM) olmak üzere çeşitli kurumlarda yaklaşık bir yıl Türkçe hazırlık programlarını tamamlayarak lisans veya lisansüstü eğitimlerine başlamaktadır. Türkçe hazırlık programından sonra öğrencilerin Türkçe ve dil becerileri bakımından mevcut durumlarının nasıl olduğuna, hazırlık eğitiminde öğrenilen dilin yeterli olup olmadığına ve okudukları programlarda karşılaştıkları sorunlara yönelik elimizde herhangi bir bilgi yoktur. Öğrencilerin öğrenme ihtiyaçlarını belirlemek ve bu doğrultuda program ve içerik oluşturmak gerekir. Hutchinson ve Waters (1987: 53) her bir dil dersi programının ihtiyaç analizi üzerinde oluşturulması gerektiğini belirtmişlerdir. "Yabancı dil eğitimini verimli kılabilmek için öncelikle öğrencilerin dil ihtiyaçlarını belirleyerek bu ihtiyaçları temel alan etkili bir programın hazırlanması gerekmektedir." (Koçer, 2013: 161). Amacı öğrencileri programlarına hazırlamak olan Türkçe hazırlık programlarının işlevini yerine getirip getiremediğini ortaya koymak ve mevcut durum analizi yaparak hataları / yanlışlıkları düzeltmek, daha etkili dil eğitimi vermek için önem arz etmektedir. Pamukkale Üniversitesi'nde verilen Türkçe hazırlık eğitiminde uluslararası öğrenciler, bir yıl içinde 960 saatlik genel Türkçe eğitiminin yanında, 140 saat akademik Türkçe ve 60 saat konuşma kulübü dersleri ile birlikte toplamda 1160 saat ders almaktadır. Bu çalışmanın amacı Pamukkale Üniversitesi'nde Türkçe hazırlık eğitimi $\mathrm{C} 1$ seviyesinde tamamlayıp bölümlerinde derslere devam eden uluslararası öğrencilerin dil yeterlilikleri ve sorunları bakımından mevcut durumlarını ortaya koymaktır.

\section{YÖNTEM}

\section{Araştırmanın Modeli}

Pamukkale Üniversitesi'nde birinci sınıfta öğrenim görmekte olan uluslararası öğrencilerin mevcut dil durumlarını ortaya koymayı amaçlayan bu çalışmada nicel araştırma yöntemlerinden tarama modeli kullanılmıştır. "Tarama yöntemi; geçmişte ya da halen var olan bir durumu var olduğu şekliyle betimlemeyi amaçlayan araştırma yaklaşımlarıdır. Araştırmaya konu olan olay, birey ya da nesne, kendi koşulları içinde olduğu gibi tanımlanmaya çalışılır." (Karasar, 2012: 77).

\section{Çalışma Grubu}

Çalışma grubunu 2019-2020 yılı bahar döneminde Pamukkale Üniversitesi'nde çeşitli fakültelerde birinci sınıfta lisans eğitimi alan, C1 düzeyinde dil seviyesine sahip 64 uluslararası 
öğrenci oluşturmaktadır. Çalışmanın gerçekleştirildiği döneminde lisans programlarının birinci sınıfında toplam 148 öğrenci öğrenim görmektedir ve bu sayının 64'üne ulaşılabilmiştir.

\section{Veri Toplama Araci}

Çalışmada, uluslararası öğrencilerin mevcut dil durumlarını ortaya koymak amacıyla Ulutaş (2016) tarafından hazırlanan Mevcut Durum Analizi (MDA) anketi uygulanmıştır. Öğrencilerin mevcut akademik dil becerilerinin ne ölçüde akademik başarılarını etkilediği ve ne tür dil problemleriyle karşılaştıklarını tespit etmeye dönük bu anket, üç bölümden oluşmaktadır. Birinci bölüm öğrencilerin demografik bilgilerini açıklamaya çalışmaktadır. Bu bölümde öğrencilerin cinsiyet, yaş, geldikleri ülke ve eğitim aldıkları alanlara ilişkin bilgiler toplamayı amaçlamaktadır.

İkinci bölüm öğrencilerin dil becerilerine yönelik genel öz değerlendirme yapmasını amaçlamaktadır. $\mathrm{Bu}$ bölümde katılımclardan dil becerileri konusunda kendilerini değerlendirmeleri istenmiştir. Dil becerileri için kendilerini en iyi olarak gördükleri beceriler için “5: çok iyi, 1: çok kötü" olacak şekilde 1'den 5'e kadar puanlamaları istenmiştir. Katılımcılar her bir dil becerisi için herhangi bir sıralama yapmadan ne durumda olduğunu ifade etmiştir. Katılımcların ilgili ortalama düzeyleri ya da değer aralıklarını belirlemek için ankete verilen en düşük puan olan 1 ile en yüksek derece olan 5 puanı aralığı araştırmacı tarafından 4 kategoriye ayrılmıştır ve "1 ile 1,8 puan arası "çok kötü", 1,8 ile 2,6 puan arası "kötü", 2,6 ile 3,4 puan arası "orta", 3,4 ile 4,2 arası "iyi" ve 4.2 ile 5 arası "çok iyi" olarak nitelendirilmiştir. Sonrasında akademik başarıları için hangi dil becerilerinin önemli olduğunun belirtilmesi istenmiştir. Katılımcılardan dil becerilerini önem sırasına göre 1 ile 4 puan arasında puanlamaları istenmiştir. Katılımcların ilgili ortalama düzeyleri ya da değer aralıklarını belirlemek için ankete verilen en düşük puan olan 1 ile en yüksek derece olan 4 puanı aralığ 4 kategoriye ayrılmıştır. " 1 ile 1,75 puan arası "önemsiz", 1,75 ile 2,5 puan arası "az önemli" ve 2,5 ile 3,25 puan arası ise "önemli" ve 3.25 ile 4 puan arası "çok önemli" olarak nitelendirilmiştir. Analiz sürecinde dil sorunların ile ilgili verilerin analiz edilmesi ve yorumlanması bu derecelendirme sistemine göre yapılandırılmıştır.

Son bölüm ise öğrencilerin dil ihtiyaç ve sorunlarını belirlemeye yönelik sorular içermektedir. Öğrencilerin dil ihtiyaç ve sorunların belirlemeye yönelik sorular, öğrencilerin öğrenim gördükleri bölümlerde okuma, yazma, dinleme ve konuşma becerilerinde ne sıklıkla sorun yaşadıklarını belirlemeye yönelik 4 farklı alt bölümden oluşan toplam 31 adet 5'li Likert tipi sorular içermektedir. Bu bölümde dil sorunları ile ilgili katılımcılardan sorun yaşama sıklıklarını 1 ile 5 puan arasında puanlamaları istenmiştir. Verilerin analizinde araştırmacı tarafından öğrencilerin Türkçe dil sorunlarının düzeylerine ilişkin ortalamaları "az sorun yaşarım, orta düzeyde sorun yaşarım ve çok sorun yaşarım" şeklinde sınıflandırılmıştır. 1 ile 5 puan arasında puanlanan anket maddelerinin ortalamaları, bu sınıflama doğrultusunda derecelendirilmiştir. Anketteki puanlamalar anlamlı bir şekilde sıralanabilen kategorilerden oluşmaktadır. Bu nedenle aralıklı bir veri türü oluşmaktadır. Bu veri türünde kategorileri düşükten yükseğe doğru sıralamak ve aynı zamanda kategoriler arasındaki farkın miktarının belirlemek olanaklıdır (de Vaus, 2002:204). Katılımcıların ilgili ortalama düzeyleri ya da değer aralıklarını belirlemek için ankete verilen en düşük puan olan 1 ile en yüksek derece olan 5 puanı aralı̆ğ üç kategoriye ayrılmıştır ve "1 ile 2,33 puan arası "az sorun yaşarım", 2,34 ile 3,66 puan arası "orta düzeyde sorun yaşarım" ve 3,67 ile 5 puan arası ise "çok sorun yaşarım" olarak nitelendirilmiş̧ir. Analiz sürecinde dil sorunların ile ilgili verilerin analiz edilmesi ve yorumlanması bu derecelendirme sistemine göre yapılandırılmıştır. Araştırma kapsamında elde edilen veriler, SPSS 22.0 programı ile analiz edilmiştir. 


\section{BULGULAR}

Birinci bölüm öğrencilerin demografik bilgilerini açıklamaya çalışmaktadır. Katılımcılara ilişkin cinsiyet, yaş, ülke ve bölüm değişkenlerine göre dağılım Tablo 1'de gösterilmektedir.

Tablo 1. Katılımcıların Demografik Özellikleri

\begin{tabular}{|c|c|c|c|}
\hline Değişken & Kategori & $\mathbf{N}$ & $\%$ \\
\hline \multirow[t]{2}{*}{ Cinsiyet } & Erkek & 47 & 73,4 \\
\hline & Kadın & 17 & 26,6 \\
\hline \multirow[t]{3}{*}{ Yaş } & $17-20$ & 18 & 28,1 \\
\hline & $21-24$ & 32 & 50,0 \\
\hline & $25-<$ & 14 & 21,9 \\
\hline \multirow[t]{30}{*}{ Ülke } & Afganistan & 15 & 23,4 \\
\hline & Yemen & 5 & 7,8 \\
\hline & Çad & 3 & 4,7 \\
\hline & Doğu Türkistan & 3 & 4,7 \\
\hline & Etiyopya & 3 & 4,7 \\
\hline & Filistin & 3 & 4,7 \\
\hline & Şili & 3 & 4,7 \\
\hline & Almanya & 2 & 3,1 \\
\hline & Azerbaycan & 2 & 3,1 \\
\hline & Bangladeş & 2 & 3,1 \\
\hline & Çin & 2 & 3,1 \\
\hline & Fransa & 2 & 3,1 \\
\hline & Moğolistan & 2 & 3,1 \\
\hline & Sudan & 2 & 3,1 \\
\hline & Benin & 1 & 1,6 \\
\hline & Gana & 1 & 1,6 \\
\hline & Hollanda & 1 & 1,6 \\
\hline & Iran & 1 & 1,6 \\
\hline & Kamerun & 1 & 1,6 \\
\hline & Kirgizistan & 1 & 1,6 \\
\hline & Komorlar & 1 & 1,6 \\
\hline & Kongo & 1 & 1,6 \\
\hline & Madagaskar & 1 & 1,6 \\
\hline & Makedonya & 1 & 1,6 \\
\hline & Nijerya & 1 & 1,6 \\
\hline & Özbekistan & 1 & 1,6 \\
\hline & Rusya & 1 & 1,6 \\
\hline & Tunus & 1 & 1,6 \\
\hline & Türkmenistan & 1 & 1,6 \\
\hline & Sosyal Bilimler & 35 & 54,7 \\
\hline \multirow[t]{2}{*}{ Bölüm } & Fen Bilimleri & 24 & 37,5 \\
\hline & Sağlık Bilimleri & 5 & 7,8 \\
\hline TOPLAM & & 64 & 100,0 \\
\hline
\end{tabular}


Tablo 1 incelendiğinde, katılımcıların yaşları 17 ila 30 arasında değişmektedir ve yaş ortalaması 22.4' tür. Bu öğrencilerden 17'si kadın (\%26,6), 47'si erkektir (\%73,4). Katılımcilar 29 farklı ülkeden gelmiştir ve bu öğrencilerin çoğu Asya ve Afrika ülkelerinden gelen öğrencilerden oluşmaktadır. Bu öğrencilerin büyük çoğunluğunu Afganistan'dan gelen öğrenciler oluşturmaktadır $(\% 23,4)$. Sonrasında ise sırasıyla Yemen $(\% 7,8)$, Çad $(\% 4,7)$, Doğu Türkistan $(\% 4,7)$, Etiyopya $(\% 4,7)$, Filistin $(\% 4,7)$ ve Şili $(\% 4,7)$ yer almaktadır. Bu yedi ülkeden gelen öğrenciler çalışmaya katılanların \%54,7'sini oluşturmaktadır.

Çalışmaya katılan uluslararası öğrenciler, 26 farklı bölümde eğitim görmektedir. Öğrencilerin eğitim gördüğü bölümler "Sosyal Bilimler", "Fen Bilimleri" ve "Sağlık Bilimleri" başlıkları altında gruplandırılmıştır. Çalışmaya katılan uluslararası öğrencilerin yarısından fazlası (N:35) Sosyal Bilimlerde öğrenim görmektedir. Bunu Fen Bilimleri (N:24) ve Sağlık Bilimleri (N:5) izlemektedir.

İkinci bölüm öğrencilerin dil becerilerine yönelik genel öz değerlendirme yapmasını amaçlamaktadır. Tablo 2, yabancı öğrencilerin dil becerileri açısından öz değerlendirme durumunu göstermektedir.

Tablo 2. Yabancı Öğrencilerin Dil Becerileri Açısından Öz Değerlendirme Durumu

\begin{tabular}{lccc}
\hline Beceriler & $\overline{\mathbf{X}}$ & Ss & Değerlendirme Düzeyi \\
\hline Dinleme & 4,28 &, 84 & Çok iyi \\
Okuma & 4,13 &, 83 & İyi \\
Konuşma & 4,08 &, 79 & İyi \\
Yazma & 2,23 & 1,08 & Kötü \\
\hline
\end{tabular}

Tablo 2 incelendiğinde yabancı öğrencilerin dinleme $(\overline{\mathrm{X}}=4,28)$ becerilerinin çok iyi düzeyde, okuma ( $\overline{\mathrm{X}}=4,13$ ) ve konuşma ( $\overline{\mathrm{X}}=4,08$ ) becerilerinin iyi düzeyde olduğunu düşündükleri açıkça görülmektedir. Yazma becerisi ( $\overline{\mathrm{X}}=2,23$ ) konusunda ise öğrenciler kendilerini başarılı olarak değerlendirmemektedir.

Katılımcların dil becerilerinin akademik başarıya olan etkisine dair değerlendirmeye Tablo 3 'te yer verilmiştir.

Tablo 3. Dil Becerilerinin Akademik Başarıya Olan Etkisine Dair Değerlendirme

\begin{tabular}{lcccc}
\hline Beceriler & $\mathbf{N}$ & $\overline{\mathbf{x}}$ & SS & $\begin{array}{c}\text { Değerlendirme } \\
\text { Düzeyi }\end{array}$ \\
\hline Dinleme & 64 & 3,36 &, 982 & Çok önemli \\
Konuşma & 64 & 2,75 &, 959 & Önemli \\
Okuma & 64 & 3,19 &, 889 & Önemli \\
Yazma & 64 & 2,77 & 1,080 & Önemli \\
\hline
\end{tabular}

Tablo 3 incelendiğinde dinleme becerisi ( $\overline{\mathrm{X}}=3,36$ ) akademik başarı için en önemli dil becerisi olduğu ifade edilmiştir. Sonrasında okuma becerisi ( $\overline{\mathrm{X}}=3,19$ ), yazma becerisi ( $\overline{\mathrm{X}}=2,77$ ) ve son olarak konuşma becerisinin ( $\overline{\mathrm{X}}=2,75$ ) akademik başarı için önemli olduğu belirtilmiştir. Bu sonuçlar dikkate alındığında öğrenciler için dinleme becerisi akademik başarının sağlanması açısında çok önemlidir. 
Katılımcıların dinleme becerileri sorunlarının ortalama puanları ve düzeylerine ilişkin bilgiler Tablo 4'te yer almaktadır.

Tablo 4. Dinleme Becerileri Sorunlarının Ortalama Puanları ve Düzeyleri

\begin{tabular}{lcccc}
\hline Dinleme Becerileri & $\mathbf{N}$ & $\overline{\mathbf{X}}$ & Ss & Düzey \\
\hline $\begin{array}{l}\text { Alanımla ilgili bir dersi ve konuşmayı dinlerken konuyu } \\
\text { özetleyerek not tutmakta sorun yaşarım. }\end{array}$ & 2,84 & 1,224 & Orta \\
$\begin{array}{l}\text { Alanımla ilgili dersleri ve konuşmaları dinlerken sözcük ve } \\
\text { terimleri anlamakta sorun yaşarım. }\end{array}$ & 2,53 & ,908 & Orta \\
$\begin{array}{l}\text { Alanımla ilgili derslerdeki sunum ve karşıllklı konuşmaları } \\
\text { dinlerken konunun içeriğini anlamakta sorun yaşarım }\end{array}$ & 2,44 & 1,153 & Orta \\
$\begin{array}{l}\text { Alanımla ilgili konferans, toplantı, panel ve seminerlerde } \\
\text { yapılan konuşmaları takip etmekte sorun yaşarım. }\end{array}$ & 2,27 &, 980 & $\mathrm{Az}$ \\
$\begin{array}{l}\text { Alanımla ilgili konuşmaları dinlerken konuşmacıların } \\
\text { konuyla ilgili kişisel görüşlerini belirlemekte sorun yaşarım. }\end{array}$ & 2,23 & 1,020 & $\mathrm{Az}$ \\
$\begin{array}{l}\text { Alanımla ilgili canlı veya kayıtlı (video, ses kaydı, radyo vb.) } \\
\text { konuşmaları dinlerken verilmek istenen ana fikri anlamakta } \\
\text { sorun yaşarım. }\end{array}$ & 2,14 & ,941 & $\mathrm{Az}$ \\
\hline
\end{tabular}

Tablo 4'e göre yabancı öğrencilerin dinleme becerisi ile ilgili yaşadıkları sorunlar incelendiğinde en büyük sorunu alanlarıyla ilgili bir dersi ve konuşmayı dinlerken konuyu özetleyerek not tutmakta sorun yaşadıkları görülmektedir $(\overline{\mathrm{X}}=2,84)$. Not tutma dinlediğini anlama ve kendi cümleleriyle tekrar (çoğunlukla kısaltarak ve önemli noktalara odaklanarak) yazmayı içermektedir. Dolayısıyla dinleme yazma becerilerinin bir birleşimi olarak da nitelendirilebilen bu beceri üzerinde zorluk yaşandığı saptanmıştır. İkinci olarak öğrenciler alanlarıyla ilgili dersleri ve konuşmaları dinlerken sözcük ve terimleri anlamakta sorun yaşadıklarını ifade etmektedir ( $\overline{\mathrm{X}}=2,53$ ). Bu da akademik kelime bilgisiyle doğrudan ilişkilidir. Öğrencilerin dinlerken yaşadığı üçüncü en büyük sorun ise derslerdeki sunum ve karşılıklı konuşmaları dinlerken konunun içeriğini anlamakta yaşadıkları sorundur.

Katılımcıların yazma becerileri sorunlarının ortalama puanları ve düzeylerine ilişkin bilgiler Tablo 5 'te yer almaktadır.

Tablo 5. Yazma Becerileri ile İlgili Yaşanılan Sorunların Ortalama Puanları ve Düzeyleri

\begin{tabular}{lcccc}
\hline Yazma Becerileri & $\mathbf{N}$ & $\overline{\mathbf{X}}$ & Ss & Düzey \\
\hline $\begin{array}{l}\text { Alanımla ilgili yazdığım yazılarda, anlam bütünlüğü olan } \\
\text { paragraflar oluşturmakta sorun yaşarım. }\end{array}$ & 64,84 & 1,057 & Orta \\
$\begin{array}{l}\text { Alanımla ilgili bir konuda edindiğim bilgileri anlaşılır bir } \\
\text { şekilde özetlemekte sorun yaşarım. }\end{array}$ & 64 & 2,69 & 1,006 & Orta \\
$\begin{array}{l}\text { Alanımla ilgili konulardaki bilgi ve görüşlerimi ilgili örnekler } \\
\text { ve destekleyici bilgilerle genişleterek (örnekleme, karşılaştırma, } \\
\text { tanık gösterme, sayısal verilerden yararlanma, betimleme, } \\
\text { kanıtlama, hikâye etme vb.) türüne uygun yazılar yazmakta } \\
\text { sorun yaşarım. }\end{array}$ & 2,66 & 1,116 & Orta \\
$\begin{array}{l}\text { Alanımla ilgili yazılarımda; alanla ilgili sözcük ve terimleri } \\
\text { uygun biçimde kullanmakta sorun yaşarım. }\end{array}$ & 2,63 & 1,047 & Orta \\
$\begin{array}{l}\text { Alanımla ilgili konferans, toplantı, panel ve seminerlerde } \\
\text { yapılan konuşmaları takip etmekte sorun yaşarım. }\end{array}$ & 64 & 2,44 &, 889 & Orta \\
\hline
\end{tabular}


Tablo 5'e göre yabancı öğrencilerin yazma becerisi ile ilgili yaşadıkları sorunlar incelendiğinde yazma becerisinde orta düzeyde sorun yaşadıkları anlaşılmaktadır. En büyük sorunu yazdıkları yazılarda, anlam bütünlüğü olan paragraflar oluşturmakta yaşadıkları görülmektedir ( $\overline{\mathbf{X}}=2,84$ ). İkinci olarak öğrenciler alanlarıyla ilgili bir konuda edindikleri bilgileri anlaşılır bir şekilde özetlemekte sorun yaşamaktadır ( $\overline{\mathrm{X}}=2,69)$. Bu iki madde öğrencilerde anlamlı bir bütün oluşturma sorununun olduğunu düşündürebilir. Üst düzey düşünme becerileri gerektiren özetleme ve anlam bütünlügünü sağlama öğrencilerin karşılaştıkları en büyük yazma sorunları olarak görülmektedir.

Katılımcıların konuşma becerileri sorunlarının ortalama puanları ve düzeylerine ilişkin bilgilere Tablo 6' da yer verilmiştir.

Tablo 6. Konuşma Becerileri ile İlgili Yaşanılan Sorunların Ortalama Puanları ve Düzeyleri

\begin{tabular}{lcccc}
\hline Konuşma Becerileri & $\mathbf{N}$ & $\overline{\mathbf{X}}$ & Ss & Düzey \\
\hline $\begin{array}{l}\text { Alanımla ilgili bir konuşmada karşı tarafın sorularına } \\
\text { uygun ve akıcı cevaplar verebilmekte sorun yaşarım. }\end{array}$ & 64 & 2,55 & 1,140 & Orta \\
$\begin{array}{l}\text { Alanımla ilgili konularda, terimleri de kullanarak sunum } \\
\text { yapmakta sorun yaşarım. }\end{array}$ & 64 & 2,52 & 1,084 & Orta \\
$\begin{array}{l}\text { Alanımla ilgili bir konuda bilgi ve görüşlerimi, akııı bir } \\
\text { biçimde ifade ederek sunum yapmakta sorun yaşarım. }\end{array}$ & 64 & 2,52 & 1,098 & Orta \\
$\begin{array}{l}\text { Türkçeyi ana dili olarak konuşan kişiler arasında geçen } \\
\text { alanımla ilgili akıcı bir konuşmaya kolaylıkla katılabilmekte } \\
\text { sorun yaşarım. }\end{array}$ & 2,50 & 1,222 & Orta \\
$\begin{array}{l}\text { Karşılıklı konuşmada ya da tartışmalarda, alanımla ilgili } \\
\text { terimleri hatasız, yerinde kullanmakta sorun yaşarım. }\end{array}$ & 2,48 & 1,168 & Orta \\
$\begin{array}{l}\text { Konuşmalarımda alanımla ilgili sözcük ve terimleri doğru } \\
\text { telaffuz edebilmekte sorun yaşarım. }\end{array}$ & 64 & 2,44 & 1,153 & Orta \\
\hline
\end{tabular}

Tablo 6'ya göre yabancı öğrencilerin konuşma becerisi ile ilgili yaşadıkları sorunlar incelendiğinde konuşma becerisinde orta düzeyde sorun yaşadıkları anlaşılmaktadır. En büyük sorunu alanlarıyla ilgili bir konuşmada karşı tarafın sorularına uygun ve akıcı cevaplar verebilmekte sorun yaşadıkları görüldüğü tespit edilmiştir ( $\overline{\mathrm{X}}=2,55)$. İkinci olarak öğrenciler alanlarıyla ilgili konularda, terimleri de kullanarak sunum yapmakta sorun yaşamaktadır ( $\overline{\mathrm{X}}$ $=2,52)$.

Katılımcların okuma becerileri sorunlarının ortalama puanları ve düzeylerine ilişkin bilgiler Tablo 7'de yer almaktadır. Tablo 7 incelendiğinde yabancı öğrencilerin okuma becerisi ile ilgili yaşadıkları en büyük sorun, alanlarıyla ilgili bir metni hızlı okurken metnin konusunu belirlemektir ( $\overline{\mathrm{X}}=2,72$ ). İkinci olarak öğrenciler alanlarıyla ilgili bir metnin içeriğini anlamakta sorun yaşamaktadır ( $\overline{\mathrm{X}}=2,61$ ). Bu iki maddeden okunulan metnin içerik ve konusunu yani genel çerçeveyi yakalamakta güçlük çektikleri görülmektedir. Buna karşın öğrenciler, okudukları akademik bir metindeki kavram ve terimlerin alanlarıyla ilgili olup olmadığını ayırt etmekte az sorun yaşamaktadırlar 
Tablo 7. Okuma Becerileri ile İlgili Yaşadıkları Sorunların Ortalama Puanları ve Düzeyleri

\begin{tabular}{|c|c|c|c|c|}
\hline Okuma Becerileri & $\mathbf{N}$ & $\overline{\mathrm{x}}$ & Ss & Düzey \\
\hline $\begin{array}{l}\text { Alanımla ilgili bir metni hızlı okurken metnin konusunu } \\
\text { belirlemekte sorun yasarım. }\end{array}$ & 64 & 2,72 & 1,061 & Orta \\
\hline Alanımla ilgili bir metnin içeriğini anlamakta sorun yaşarım. & 64 & 2,61 & 1,002 & Orta \\
\hline $\begin{array}{l}\text { Alanımla ilgili uzun metinlerde, alt bölümlerin konu ile } \\
\text { arasındaki ilişkiyi belirlemekte sorun yaşarım. }\end{array}$ & 64 & 2,58 & 1,036 & Orta \\
\hline $\begin{array}{l}\text { Alanımla ilgili metinlerdeki öznel (subjektif) ve nesnel (objektif) } \\
\text { yargıları ayırt etmekte sorun yaşarım. }\end{array}$ & 64 & 2,53 & ,975 & Orta \\
\hline $\begin{array}{l}\text { Alanımla ilgili akademik metinlerde (kitap, bildiri, makale, tez, } \\
\text { bilimsel rapor...vb.) kullanılan sözcük ve terimleri anlamakta } \\
\text { sorun yaşarım. }\end{array}$ & 64 & 2,52 & 1,054 & Orta \\
\hline $\begin{array}{l}\text { Alanımla ilgili akademik bir metindeki ana düşünce ve yardımcı } \\
\text { düşünceleri belirlemekte sorun yaşarım. }\end{array}$ & 64 & 2,42 & 1,066 & Orta \\
\hline $\begin{array}{l}\text { Alanımla ilgili metinlerde dolaylı olarak ifade edilen (örtülü } \\
\text { bilgiler, ilişkiler, kişisel fikir ve düşünceler) unsurları anlamakta } \\
\text { sorun yaşarım. }\end{array}$ & 64 & 2,42 & ,905 & Orta \\
\hline $\begin{array}{l}\text { Okuduğum akademik bir metindeki kavram ve terimlerin } \\
\text { alanımla ilgili olup olmadığını ayırt etmekte sorun yaşarım. }\end{array}$ & 64 & 2,31 & 941 & $\mathrm{Az}$ \\
\hline $\begin{array}{l}\text { Alanımla ilgili metinlerindeki temel veri ve değerlerin (tablo, } \\
\text { şekil, sayısal veri, grafik, vb.) işlevlerini anlamakta sorun } \\
\text { yaşarım. }\end{array}$ & 64 & 2,06 & 1,006 & $\mathrm{Az}$ \\
\hline
\end{tabular}

\section{SONUÇ ve TARTIŞMA}

Bu çalışma, Pamukkale Üniversitesi'nde birinci sınıfta öğrenim görmekte olan uluslararası öğrencilerin mevcut dil durumlarını ortaya koymak amacıyla yapılmıştır. Yapılan çalışmada katılımcllar, dinleme becerilerinin çok iyi düzeyde olduğunu, yazma becerilerinin ise kötü düzeyde olduğunu düşünmektedir. Kendilerini okuma ve konuşma becerilerinde iyi düzeyde oldukları şeklinde değerlendirmektedirler. Ellialtı ve Batur (2021) yapmış oldukları çalışmada dinleme becerisinin öğrenciler için en kolay gelişen beceri olduğunu ortaya koymuşlardır. Açık (2008)'ın çalışmasında ortaya koyduğu \%40 oranı ile yazma becerisinin en çok sorunun yaşanan beceri olduğu görülmüştür. Çalışmadan elde edilen sonuca göre temel dil becerilerine ilişkin yazma becerisi en çok zorlanılan beceridir. Bu sonuç daha önceki çalışmaların sonuçlarıyla örtüşmektedir (Konyar ve Yılmaz, 2021; Demir, 2017; Ekmekçi, 2017; Şahin ve Demirtaş, 2014; Biçer vd., 2014; Tok, 2013, Açık, 2008). Bu durumun lisansüstü öğrenciler için de aynı olduğu Haidari ve Yelken (2018)'in çalışma sonucunda görülmektedir. Yazma becerisi bilgi ve zaman gerektiren, edinilmesi ve kullanılması zor bir beceridir (Batur ve Ellialtı, 2018).

Katılımcıların akademik başarı için en önemli olduğunu düşündükleri beceri dinleme becerisi, en az önemli olduğunu düşündükleri dil becerisi ise yazmadır. Öğrencilerin kendilerini çok iyi durumda olduklarını belirttikleri dinleme becerisinin akademik başarının sağlanması açısından çok önemli olduğu düşünülmektedir. Demir (2017)'in çalışmasına göre öğrenciler bölüm derslerinde en sık dinleme becerisini kullanmaktadır. Dolayısıyla en fazla kullanılan dinleme becerisinin başarı konusunda da önemli olduğu görülmektedir. En zor beceri olarak değerlendirilen yazma becerisinin ise diğer temel beceriler ile kıyaslandığında akademik başarıya en az katkıda bulunan beceri olarak değerlendirilmektedir. Christison ve Krahnke (1986, akt. Demir, 2017: 207) ABD’deki uluslararası öğrencilerin en faz dinleme becerisini kullandıklarını, 
buna karşın en az yazma becerisini kullandıklarını tespit etmişlerdir. Bu tespit çalışmamızın sonucuyla örtüşmektedir.

Tüm beceriler değerlendirildiğinde, öğrencilerin çok yoğun bir şekilde sorun yaşadığı bir beceriye rastlanmamıştır. Genel olarak öğrenciler en çok alanlarıyla ilgili bir dersi ve konuşmayı dinlerken konuyu özetleyerek not tutmakta; yazdıkları yazılarda, anlam bütünlüğü olan paragraflar oluşturmakta ve alanlarıyla ilgili bir metni hızlı okurken metnin konusunu belirlemekte sorun yaşadıkları görülmektedir. Okuma becerilerine ilişkin sonuçlar incelendiğinde, öğrenciler okudukları akademik bir metindeki kavram ve terimlerin alanlarıyla ilgili olup olmadığını ayırt etmekte az sorun yaşadığı görülmektedir. Bu sonuç Demir (2017)'in ortaya koyduğu akademik okumada öğrencilerin en çok zorlandı̆̆ı alt becerinin, "metinlerdeki bölümümle ilgili terimleri anlayabilmektir" sonucuyla çelişmektedir. Öğrenciler ayrıca metinlerindeki temel veri ve değerlerin (tablo, şekil, sayısal veri, grafik, vb.) işlevlerini anlamakta az sorun yaşadıklarını belirtmişlerdir.

$\mathrm{Bu}$ veriler ışığında, Türkçe hazırlık programlarında akademik başarı için önemli olduğu düşünülen dinleme becerisine ağırlık verilmelidir. Ayrıca öğrencilerin zorluk yaşadığını ifade ettikleri yazma becerisine yönelik çalışmalar yapılmadır. Not alma ve özet çıkarma gibi yazmanın alt becerilerine de programda önem verilmelidir. Türkçe hazırlık derslerinde hızlı okuma çalışmalarına zaman ayrılmalı ve programa dahil edilmelidir. Üniversitelerdeki uluslararası öğrencilerin birincil hedefi alanlarıyla ilgili bilgi edinmek ve diploma sahibi olmaktır. Bu bağlamda öğrencilerin temel ihtiyaçlarının akademik düzeyde ve içerikte dil öğrenmek olduğu dikkate alınmalıdır. C1 kuru bittikten sonra verilen akademik Türkçe dersleri, imkanlar elverdiği sürece ve alan temelli olacak şekilde, B1 seviyesi sonrasında verilmeye başlanmalıdır.

\section{KAYNAKÇA}

Açık, F. (2008). Türkiye'de yabanclara Türkçe öğretilirken karşılaşılan sorunlar ve çözüm önerileri. 1. Uluslararası Türkçe Eğitimi ve Öğretimi Sempozyumu Bildirileri, Doğu Akdeniz Üniversitesi Eğitim Fakültesi Türkçe Eğitimi Bölümü, 27-28 Mart, Gazimağusa, K.K.T.C.

Ali, A. A. (2011). A needs analysis for designing an ESP syllabus for the students of Sudan Naval Academy. Unpublished doctoral dissertation, Al Neelain University.

Arroyyani, R. and Nurhayati, L. (2019). Students' necessities, lacks and wants on ICT-based English for nursing students. Anglo-Saxon: Jurnal Ilmiah Program Studi Pendidikan Bahasa Inggris, 10(2), 159-176.

Batur, Z. ve Ellialtı, M. (2018). Türkiye ve İngiltere'deki 11-14 yaş öğrencilerinin ana dili çalışma kitaplarındaki yazma etkinliklerinin incelenmesi. International Journal of Language Academy. 23, 419-427.

Berwick, R (1989) Needs assessment in language programming; from theory to practice. In: Johnson, RK (ed.) The Second Language Curriculum, Cambridge University Press.

Biçer, N., Çoban, İ. ve Bakır, S. (2014). Türkçe öğrenen yabancı öğrencilerin karşılaştığı sorunlar: Atatürk Üniversitesi örneği. Journal Of International Social Research, 7(29), 125-135.

Brown, J. D. (1995). The elements of language curriculum: A systematic approach to program development. Boston: Heinle and Heinle Publishers.

Çalışkan, N., ve Bayraktar, S. (2012). Yabancılara Türkçe öğretimi konusunda bir ihtiyaç analizi: Kahire Yunus Emre Türk Kültür Merkezi örneği. VII. Uluslararası Türk Dil Kurultayı, 24- 28 Eylül, Ankara. 
Çalışkan, N. ve Çangal, Ö. (2013). Yabancılara Türkçe öğretiminde dil ihtiyaç analizi: BosnaHersek örneği. Abant İzzet Baysal Üniversitesi Eğitim Fakültesi Dergisi, 13(2), 310-334.

Çelik, N. ve İpek, S. (2019). Yabancı dil olarak Türkçe öğretiminde dil ihtiyaç analizi: Polonya örneği. Aydın Tömer Dil Dergisi, 4(2), 101-136.

De Vaus, D. (2002). Surveys in social research (5th edition). London: Routledge.

Deliktaş, A. (2019). Yabancı dil olarak Türkçe öğretiminde dil ihtiyaç analizi: İstanbul örneği (Yüksek lisans tezi). İstanbul Üniversitesi Sosyal Bilimler Enstitüsü, İstanbul.

Demir, D. (2017). Uluslararası Öğrencilerin Akademik Türkçe İhtiyaçları. Yayımlanmamış Doktora Tezi, Hacettepe Üniversitesi Türkiyat Araştırmaları Enstitüsü, Ankara.

Demir, D. ve Genç, A. (2018). Akademik Türkçe etkinliklerine yönelik öğrenci ve öğretim elemanı görüşleri. HÜTAD Hacettepe Üniversitesi Türkiyat Araştırmaları Dergisi, 15(28), 91-104.

Demir, D. and Genç, A. (2019). Academic Turkish for international students: Problems and suggestions. Journal of Language and Linguistic Studies, 15(1), 34-47.

Dudley-Evans, T. and St John, M. J. (1998). Developments in English for specific purposes: A multidisciplinary approach. Cambridge university press.

Ekmekçi, V. (2017). Yabancılara Türkçe öğretiminde akademik okuryazarlık öğretimine yönelik bir eylem araştırması (Doktora tezi), Erciyes Üniversitesi, Kayseri.

Ellialtı, M. ve Batur, Z. (2021). Academic listening states of the international university students in Turkey, International Journal of Education and Literacy Studies, 9(3).

Gürbüz, R. ve Güleç, İ. (2016). Türkiye'de eğitim gören yabancı öğrencilerin Türkçeye ilişkin görüşleri: Sakarya üniversitesi örneği. Sakarya University Journal of Education, 6(2), 141-153.

Gürler, İ. (2018). Evaluation of the current curriculum in elt departments from the perspectives of lecturers and students: A needs analysis. Yayınlanmamış Doktora Tezi, Atatürk Üniversitesi, Erzurum.

Haidari, S. M., and Yeken, T. Y. (2018). Language difficulties that international postgraduate students experience during their education with the medium of Turkish language. Dil ve Dilbilimi Çalışmaları Dergisi, 14(1), 194-210.

Hutchinson, T. and Waters, A. (1987). English for specific purposes: A learning-centred approach. Cambridge University Press.

Hyland, K. (2006). English for academic purposes: An advanced resource book. New York: Routledge.

Jordan, R. R. (1997). English for academic purposes: A guide and resource book for teachers. Cambridge: Cambridge University Press.

Karasar, N. (2012). Bilimsel araştırma yöntemleri. Nobel Yayınları.

Koçer, Ö. (2013). Program geliştirmenin ilk basamağı: yabancı dil olarak Türkçe öğretiminde ihtiyaç ve durum analizi. Ĕgitim ve Bilim, 38(169), 159-174.

Konyar, M. ve Yılmaz, F. (2021). Uluslararası öğrenciler için akademik Türkçe ders içeriği hazırlanmasına yönelik bir araştırma: İhtiyaçlar ve öneriler. International Journal of Languages' Education and Teachin, 9(1), 156-179.

Long, M. H. (2005). Methodological issues in learner needs analysis. Second language needs analysis içinde (s. 19-76). Cambridge: Cambridge University Press. 
Rahman, M. (2015). English for specific purposes (ESP): A holistic review. Universal Journal of Educational Research, 3(1), 24-31.

Richards, J. C. (1984). Language curriculum development. RELC journal, 15(1), 1-29.

Richterich R. and Chancerel J. (1980). Identifying the needs of adults learning a foreign language. Oxford: Pergamon Press.

Robinson P. (1991). ESP today: A practitioner's guide. New York: Prentice Hall.

Şahin, M. ve Demirtaş, H. (2014). Üniversitelerde yabancı uyruklu öğrencilerin akademik başarı düzeyleri, yaşadıkları sorunlar ve çözüm önerileri. Milli Ĕ̆itim Dergisi,44(204), 88-113.

Tok, M. (2013). Türkçenin yabancı dil olarak öğretiminde akademik yazma ihtiyacı. Mustafa Kemal Üniversitesi Sosyal Bilimler Enstitüsü Dergisi, 23, 1-25.

Ulutaş, M. (2016) Türkiye'de yükseköğrenim görecek yabancılar için özel amaçlı Türkçe öğretimine yönelik program geliştirme: Bir model önerisi (Doktora Tezi), Gazi Üniversitesi, Eğitim Bilimleri Enstitüsü, Ankara.

West R. (1994). Needs analysis in language teaching. Language Teaching, 27, 1-19.

Yilmaz, F. and Konyar, M. (2017). Turkish academic language needs analysis in teaching Turkish as a foreign language. International Journal of Language Academy, 5(4), 223-233. 